\title{
PHILOSOPHY
}

THE JOURNAL

OF

THE ROYAL INSTITUTE OF PHILOSOPHY

\author{
EDITED BY \\ H. B. ACTON \\ ASSISTED BY \\ S. C. BROWN
}

VOL. XLIV-1969

LONDON:

MACMILLAN \& CO., LIMITED

LITTLE ESSEX STREET, W.C.2

1969 


\section{CONTENTS OF VOLUME XLIV}

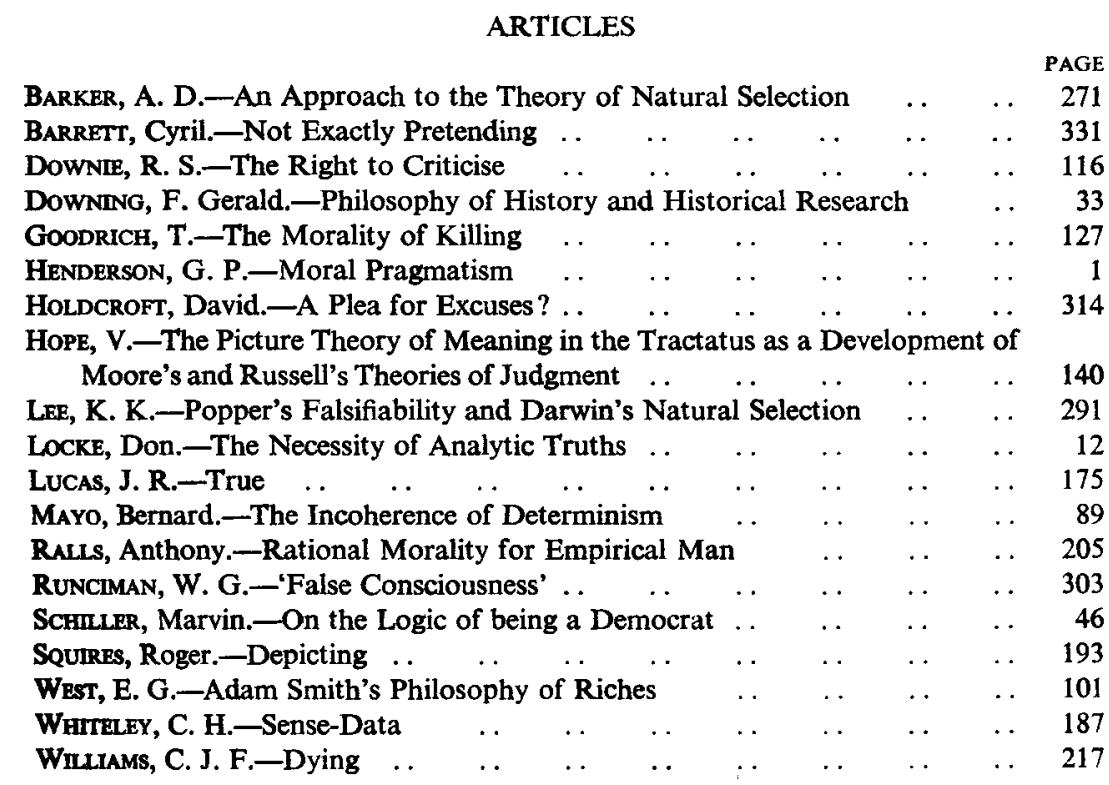

\section{DISCUSSION}

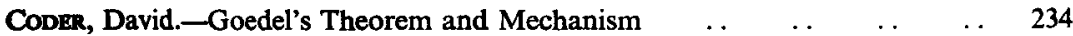

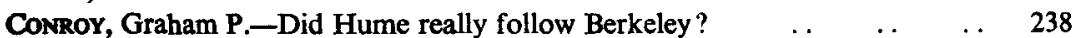

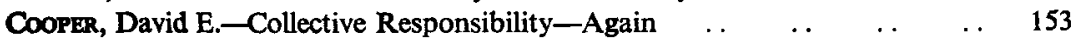

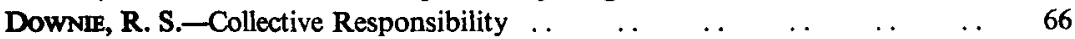

HoLborow, L. C.-Promising, Prescribing and Playing-along $\quad \ldots \quad$.

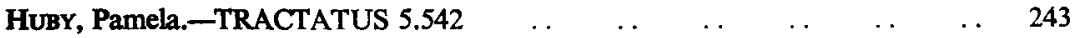

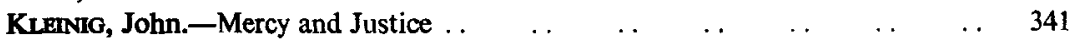

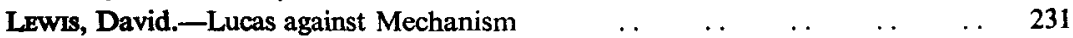

Nrelsen, Kai.-Wittgensteinian Fideism: A Reply to Hudson $\quad \ldots \quad \ldots \quad \ldots \quad \ldots \quad 63$

SWINBURNe, R. G.-Whole and Part in Cosmological Arguments $\quad \ldots . \quad \ldots \quad 339$

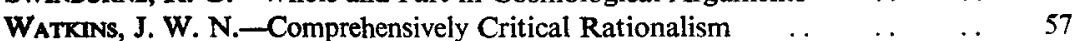

\section{REVIEW ARTICLES}

Hesse, Mary B.-Talk of God' $\quad$.

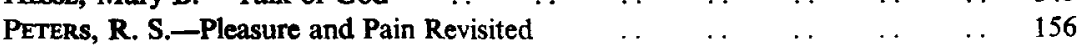




\section{NEW BOOKS}

Aune, Bruce.-Knowledge, Mind and Nature (D. W. Hamlyn) . . . . . .

Bodson, Arthur.-La Morale, Sociale des Derniers Stoiciens, Séneque, Epictete,

$\begin{array}{lllllllllll}\text { et Marc Aurele } & \ldots & \ldots & \ldots & \ldots & \ldots & \ldots & \ldots & \ldots & \ldots & \end{array}$

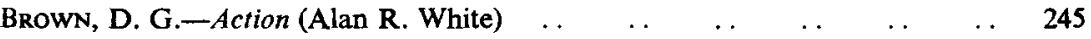

Cowley, Fraser.-A Critique of British Empiricism (F. C. T. Moore) _. $\quad$. 247

Derrida, Jacques._La Voix et la Phénomène (Wolfe Mays) $\quad \ldots \quad$. $\quad \ldots \quad 77$

Davto, A. C.-Analytical Philosophy of Knowledge (Don Locke) ～. $\quad$. 354

GRICE, Geoffrey Russell.-The Grounds of Moral Judgment (Les Holborow) ～. . 253

HARPER, Ralph._Human Love: Existential and Mystical (Peter A. Bertocci) $\quad$. 167

Hirst, R. J. (Ed.).-Philosophy: An Outline for the Intending Student (Russell Grice)

Hillard C.-Anomalies and Scientific Theories (R. G. Swinburne) .. 166

JASPERS, Karl._-Philosophical Faith and Revelation (Eva Schaper) ～. . . 76

KERFERD, G. B., and D. E. Walford.-(Translated and introduced by) Kant:

Selected Pre-Critical Writings and Correspondence with Beck . . . . . . 164

LANGFoRd, Glenn.-Philosophy and Education (Paul H. Hirst) .. . . . 255

LISTOWEL, Earl of.-Modern Aesthetics: An Historical Introduction (Eva Schaper) 74

LLoYD, G. E. R.-Aristotle: The Growth and Structure of his Thought (A. R.

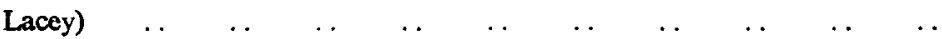

Madden, Edward H. and Peter H. Hare.-Evil and the Concept of God (John

$\begin{array}{llllllllllll}\text { Hick) } & \ldots & \ldots & \ldots & \ldots & \ldots & \ldots & \ldots & \ldots & \ldots & \ldots & 160\end{array}$

NARVESON, Jan._-Morality and Utility (J. B. Schneewind) $\quad \ldots \quad \ldots \quad \ldots \quad \ldots \quad 162$

Olafson, Frederick A.-Principles and Persons: An Ethical Interpretation of

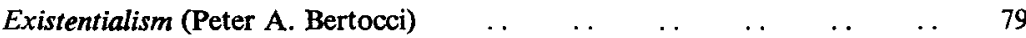

OWEN, G. E. L. (Ed.).-Aristotle on Dialectic. The Topics (A. R. Lacey) ～. 248

Plantinga, Alvin.-_God and Other Minds (R. W. Newell) $\quad \ldots \quad$. $\quad \ldots \quad \ldots 71$

Portzous, A. J. D., R. D. Maclennan and G. E. Davie (Ed.).-The Credibility of Divine Existence: The Collected Papers of Norman Kemp Smith (W. H.

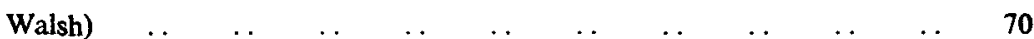

Porter, Burton F.-Deity and Morality (H. P. Owen) $\quad \ldots \quad$. . $\quad \ldots \quad \ldots \quad \ldots 1$

Rossi, Paola.-Francis Bacon: From Magic to Science (Peter Alexander) ～. 352

SchaPER, Eva.-Prelude to Aesthetics (P. H. Jones) $\quad \ldots \quad$. . $\quad \ldots \quad \ldots \quad \ldots \quad 351$

SMART, Ninian.-The Yogi and the Devotee: the interplay between the Upanishads

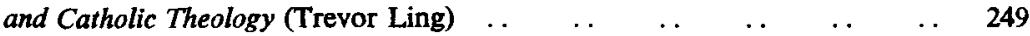

WEIL, Simone.-On Science, Necessity and the Love of God (Frederick Rosen) 250

WollHeIM, Richard._Art and its Objects (Eva Schaper) . . $\quad \ldots \quad \ldots \quad \ldots \quad \ldots \quad 350$ 


\section{INSTITUTE NOTICES}

$\begin{array}{lllllllllll}\text { Aesthetics Conference .. } & \ldots & \ldots & \ldots & \ldots & \ldots & \ldots & \ldots & \ldots & 173\end{array}$

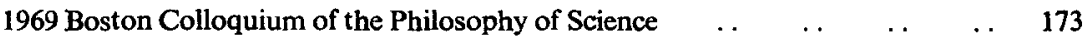

$\begin{array}{llllllllll}\text { Changes of Address } & \ldots & \ldots & \ldots & \ldots & \ldots & \ldots & \ldots & \ldots & 88,262\end{array}$

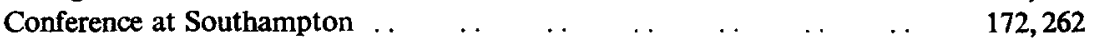

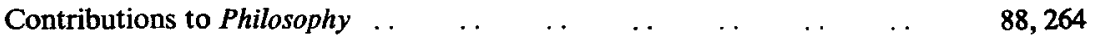

Husserl and the Idea of Phenomenology

$\begin{array}{llllllllll}\text { Index of Volume XLIII } & \ldots & \ldots & \ldots & \ldots & \ldots & \ldots & \ldots & \ldots & 88\end{array}$

$\begin{array}{llllllll}\text { Journal of the British Society of Phenomenology } & \ldots & \ldots & \ldots & \ldots & \ldots & 88\end{array}$

$\begin{array}{llllllllllll}\text { Kant Congress .. } & \ldots & \ldots & \ldots & \ldots & \ldots & \ldots & \ldots & \ldots & \ldots & 88\end{array}$

Lecture Programme 1968/69 ..

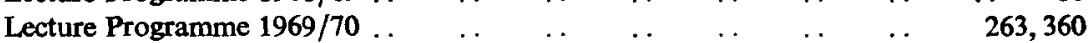

$\begin{array}{llllllllll}\text { Members' Subscriptions } & \ldots & \ldots & \ldots & \ldots & \ldots & \ldots & \ldots & \ldots & 173\end{array}$

$\begin{array}{llllllll}\text { Notes on Contributors } & \ldots & \ldots & \ldots & \ldots & \ldots & \ldots & 86,172,262,360\end{array}$

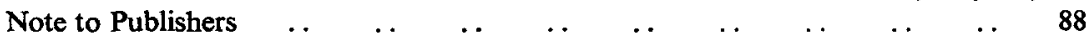

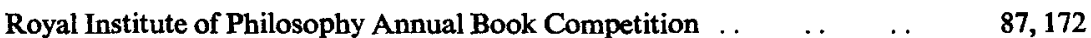

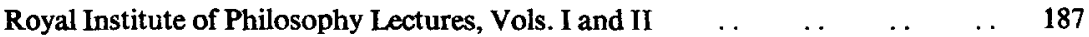

Officers of the Institute $\quad$.

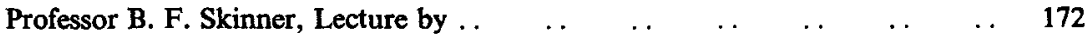

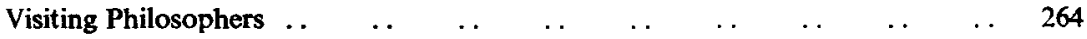

